\title{
Medicinal Plants as a Safe Target for Treatment of Cancer
}

\section{*Khaled Nabih Rashed}

Pharmacognosy Department, National Research Centre, Dokki, Giza, Egypt

\begin{abstract}
Cancer is a major public health problem, almost everywhere in the world. An attempt has been made to give a note about some medicinal plants used for the prevention and treatment of cancer. Herbal medicines have a vital role in the prevention and treatment of cancer. Plants have been used for treating diseases since time immemorial. More than $50 \%$ of modern drugs in clinical use are of natural products. In the present editorial, an attempt has been made to study the plants that have been used in the treatment of cancer.of attracting nurses to ICU.
\end{abstract}

Keywords: Anticancer; Medicinal plants; Herbal medicine; Cancer treatment

Cancer is a major public health burden in both developed and developing countries. It was estimated that there were 10.9 million new cases, 6.7 million deaths, and 24.6 million persons living with cancer around the world in 2012 [1-3]. Natural products especially plants have been used for the treatment of various diseases for thousands of years. The Ebers Papyrus, the best known Egyptian pharmaceutical record which documented over 700 drugs, represents the history of Egyptian medicine dated from 1500 BC. The Chinese Materia Medica, which describes more than 600 medicinal plants, has been well documented with the first record dating from about 1100 BC. [4]. Many medicinal plants have anti-cancer activity as Allium sativum contains more than 100 biologically useful secondary metabolites, which include alliin, alliinase, allicin, Sallyl- cysteine (SAC), Diallyl disulphide (DADS),

Diallyl trisulphide (DATS) and Methylallyl trisulphides [5]. Annona species contain acetogenins, which possess significant cytotoxic activity against leukaemia and sarcoma. Acetogenins are found to be effective in the treatment of nasopharyngeal carcinoma [6]. Arctium lappa contains potent anticancer factors that prevent mutations in the oncogenes. It has been used in the treatment of malignant melanoma, lymphoma and cancers of the pancreas, breast, ovary, oesophagus, bladder, bile duct and the bone. A study revealed that it reduces the size of tumour, relieves the pain and prolongs the survival period [7]. Gossypium barbadense contains gossypol. Recent studies have revealed that gossypol possesses selective toxicity towards cancerous cells [8]. Gyrophora esculenta is a mushroom that inhibits growth of cancer by enhancing activity of the natural killer cells. A study revealed that it inhibits carcinogenesis and metastases [8]. Egypt, a semi- arid region has abundant plants resources, which are traditionally used for various disorders. Some Egyptian flora are used as anticancer agents as Luffa aegyptiaca (sponge gourd), Solenostemma arghe (argel), Cassia italica (senegal senna), Ocimum basillcum (basil), Colocasia antiguorum (taro), Beta vulgaris (beet) and fruit of Capsicum frutescens (chili pepper). Anticancer activities of these plants were observed in vitro against acute myeloid leukemia (AML) and acute lymphocyte leukemia (ALL); and in vivo against Ehrlich as cites carcinoma cells (EACC). Solenostemma arghel hot water extract significantly reduced EACC induced tumor growth and delayed animal death (with EACC) by 29 days. Among all the extracts S. arghel showed high cytotoxicity (66-90\%) on ALL and AML cells from patients [9].

\section{References}

1. Parkin DM, Bray F, Ferlay J, Pisani P (2005) Global cancer statistics, 2002. CA Cancer J Clin 55: 74-108.

2. Dervan PA (1999) Understanding Cancer. Jefferson, NC: McFarland.

3. Hartwell JL (1982) Plants used against cancer: a survey. Lawrence, MA Quarterman Publications, 438-439.

4. Cragg GM, Newman DJ, Snader KM (1997) Natural products in drug discovery and development. J Nat Prod 60: 52-60.

5. Scharfenberg K, Wagner R, Wagner KG (1990) The cytotoxic effect of ajoene a natural product from garlic, investigated with different cell lines. Cancer Lett 53: 103-108.

6. "The Wealth of India" (1985) A dictionary of Indian raw materials and industria products Vol-I, 80.

7. "The Wealth of India" (1985) A dictionary of Indian raw materials and industrial products Vol-I, 109.

8. Ambasta SP (2000) "The Useful Plant Of India", Fourth Edition, National Institution of Sci. Communication, Delhi, 243-253.

9. Amr NA, Ahmed AE, Khalid AE, David AL, Alan C, et al, (2009) Anti-cancer and anti-oxidant activity of some Egyptian medicinal plants. Journal of Medicinal Plants Research 3: 799-808.
*Corresponding author: Khaled Nabih Rashed, Pharmacognosy Department National Research Centre, Dokki, Giza, Egypt, Tel: 01003642233; E-mail khalednabih2015@yahoo.co.uk

Received January 16, 2014; Accepted January 18, 2014; Published January 20,2014

Citation: Rashed KN (2014) Medicinal Plants as a Safe Target for Treatment of Cancer. Nat Prod Chem Res 2 :e106. doi:10.4172/2329-6836.1000e106

Copyright: (c) 2014 Rashed KN. This is an open-access article distributed under the terms of the Creative Commons Attribution License, which permits unrestricted use, distribution, and reproduction in any medium, provided the original author and source are credited. 